\title{
The Inconsistency of Nigeria's Education System and Its Implication for Curriculum Implementation
}

\author{
Olayemi Aderokun Asaaju \\ Adeyemi College of Education, Ondo, Nigeria
}

\begin{abstract}
The inconsistency of the education system in Nigeria in the last 50 years has brought the system into a state of confusion. The 6:5:2:3 system of education which was termed too "bookish" was replaced by the 6:3:3:4 system to accommodate vocational subjects especially for those students who may not be academically inclined; this no doubt was a reflection of the flexible nature of a good curriculum. Implementation of this latter system was a complete failure before it metamorphosed into the latest one- the 9:3:4. As the nation was trying to adjust to this new system, there is a new one, the 1:6:3:3:4 though not yet implemented. It has been observed however that these changes have not translated into quality education delivery in Nigeria public schools as it were, an indication that operational factors are defective. One of such factors identified in this paper is inadequate information and preparation of teachers who will implement the curriculum. Another factor is poor funding which has culminated in lack of basic infrastructure and instructional materials that can enhance teachers' competence and students' performance. Curriculum implementation as the pivot for the achievement of education goals deserves utmost priority. Teachers must be adequately informed and prepared through training and retraining to effectively interpret the curriculum because they will to a larger extent determine the way of the tide that blows the entire education structure. Education as an expensive enterprise must be well-funded by government, public schools adequately equipped with the requisite quality infrastructure, only then can the desired change be realized and the goals of education achieved.
\end{abstract}

Keywords: education system, educational policy, curriculum implementation, inconsistency, operational factors

The foundation for the formulation of educational policies in Nigeria has its roots traceable to the 1925 policy issued by the Advisory Committee on Native Education in British Tropical African Dependencies set up by the Colonial Office in London. According to Fafunwa (1974, pp. 123-125), "The British colonial government issued its first educational policy on education in $1925 \ldots$ It was the first policy paper to be issued on African education by the colonial government since modern education was introduced in Nigeria 83 years earlier". Since this time, the educational structure has changed in the areas of curriculum innovation and policy formulation, some of which were progressive and some retrogressive.

The progressive developments witnessed expansion in student enrollment, increase in the number of schools and institutions, establishment of the Teachers Registration Council (TRC), introduction of Information and Communication Technology (ICT), Social Studies and Citizenship Education into the school curriculum,

Corresponding author: Olayemi Aderokun Asaaju, M.Ed., member, Teachers Registration Council of Nigeria (TRCN) Department of Special Education and Curriculum Studies, Adeyemi College of Education, Ondo, Nigeria; research fields: science education, curriculum studies, and teacher education/training. E-mail: modadeola64@yahoo.com. 
and formulation of a clear-cut policy on early childhood/pre-primary education for children between zero and six years among others. The retrogressive aspect was and is, the inconsistent system of education that has regressed quality of education offered in Nigeria public schools which is the focus of this paper. Policy actualization rests on the workability of a system; there cannot be a policy in the absence of a system to actualize its objectives. In this paper, the words policy and system are used interchangeably as the writer believes they are two sides of the same coin.

\section{Statement of the Problem}

It has been observed that the numerous changes to the educational policy/system over the years have not translated into quality education delivery in Nigeria public schools as it were, an indication that operational factors for policy implementation are either in shortfall, defective, or unavailable. The system has become rather clumsy and confusing to Nigerians; a situation where Nigerians and particularly teachers are unsure of what happens next. As Asaaju (2011) asserted, the Nigerian educational system is in a confused state, an assertion in tandem with Fafunwa (1981) cited in Adeyemi (1995, p. 28), “Our present system is like Joseph's multi-colour dress with several patches here and there and with threads running in all directions. There are many routes and too many dead ends within the system". Fafunwa's view was aired over 30 years ago and the situation has not improved in any way, if anything, it has worsened. Nigerian teachers, the implementers of a vast majority of educational policies are almost completely oblivious of what happens next in their supposed tool of trade. Before they settle down to a particular education system and its intricacies, there is a change they are neither informed about nor prepared for. Aside this, Nigerian teachers are in a precarious situation of non-performance due to lack of basic infrastructure and instructional materials teachers need to enhance their competence and enhance students' performance, a fallout from inadequate funding of the education sector.

What are educational policies?

Akindele and Adegbite (2005, p. 77) view policy as "the government statement on the planned course of action, contained in national documents such as the Constitution and the National Policy on Education" while the Wikipedia describes education policy as the collection of laws and rules that govern the operation of education systems. "A nation's policy on education is government's way of realizing that part of the national goals which can be achieved using education as a tool" (Federal Republic of Nigeria, 2004, p. 6). According to Jaiyeoba and Atanda (2005) in Ekundayo (2010), education policy represents definite courses of action proposed by the government in power or an executive authority and adopted as expedient to the issues and problems of education. To Ocho (2003) in Suleiman (2010, p. 281), "Policies in education represent the thinking of government as to the lines along which the affairs of education should be conducted... Educational policy statements are designed to guide professionals with regard to how the educational system should operate". If education as earlier said can be used as a tool to achieve national goals via education policies, why look elsewhere for answers to why Nigeria's national and educational goals are not being achieved?

\section{The National Policy on Education}

The history of the education system and curriculum development in Nigeria will be incomplete without the monumental, well acclaimed, and unrivalled 1969 National Curriculum Conference which held on September 8-12, in the University of Lagos. It was unprecedented in the history of education not only in Nigeria but in Africa, and as Fafunwa (1974, p. 210) affirmed, "Such a national conference has never been held before, not 
even in Europe, Asia, or America". This conference was a landmark achievement as it marked the beginning of a new era in formulation of education policy in post-colonial Nigeria. The outcome of this conference birthed the National Policy on Education which was first published in 1977 to serve as the main policy document of Nigeria's education structure. The policy, a veritable means of bridging the uniformity gap that existed in the different regions then was revised in 1981, 1998, and 2004. It also remains the only policy document, guiding the conduct of education at all levels in Nigeria.

\section{The Federal Ministry of Education}

The Nigerian Federal Ministry of Education is the government body that directs education in Nigeria. It was established in 1988. Its functions include:

(1) Formulating a national policy on education;

(2) Collecting and collating data for purposes of educational planning and financing;

(3) Maintaining uniform standards of education throughout the country;

(4) Controlling the quality of education in the country through the supervisory role of the Inspectorate Services Department within the ministry;

(5) Harmonizing educational policies and procedures of all the states of the federation through the instrumentality of the National Council on Education;

(6) Effecting co-operation in educational matters on an international scale;

(7) Developing curricula and syllabuses at the national level in conjunction with other bodies.

It is evident from the above that the onus task of policy formulation, harmonization, and actualization rest with the Federal Government of Nigeria through the Federal Ministry of Education. Therefore, if education policies are not achieving their purposes, these functions are probably either not receiving the desired attention or being duly performed.

\section{Nigerian Educational Research and Development Council (NERDC)}

The Nigerian Educational Research and Development Council (NERDC) is a curriculum agency established by Decree 53 of 1988 following a merger of four bodies - the Nigerian Educational Research Council (NERC), the Comparative Education Study and Adaptation Centre (CESAC), the Nigerian Book Development Centre (NBDC), and the Nigerian Language Centre (NLC). This council is responsible for numerous educational functions chief among which is to promote the development of curricula at all levels of the educational system. This singular function underscores the significance of the agency in policy formulation and implementation. The agency is also responsible for publishing the National Policy on Education in Nigeria.

\section{Inconsistencies in the Educational Policies/System: Real or Imagined}

The education sector today remains the most unpredictable in Nigeria, a situation that has bred poor service delivery, mass failure in examinations, confusion and conflicts of intentions among stakeholders. Alhaji Babs Animashaun, the Coordinator of National Parents Teachers Association of Nigeria (NAPTAN) attributed the declining standards of education in Nigeria to policy inconsistency. In his words, "Absence of a coherent set of policies for the nation's education sector has resulted in the absence of qualitative education at all levels... Inadequate funding and policy inconsistency are two major challenges our education is facing" (Daily Trust Online, August 12, 2010). 
Professor Dibu Ojerinde, the Registrar of Joint Admissions and Matriculation Board (JAMB) maintained that the inefficiency that had characterized the education system could not be divorced from policy inconsistency of the past administrations, "Inconsistent education policy making had contributed immensely to the worrisome failure in public examinations" (Daily Independent Online, March 28, 2011).

Sheikh Ahmed Lemu, National President of Islamic Education Trust has this to say, “... but the major problem of the sector (education) is that of policy inconsistency as every government wants to introduce its own policies and through this, education suffers, so also the standard" (National Mirror Online, February 2, 2012). Former Prime Minister of Ireland Mr. Bertie Ahern has cautioned the federal government and government at all levels on the need to ensure consistent and transparent policies... "Comprehensive education policies had been shown to provide solid foundations for larger countries..." (Vanguard Online, April 11, 2011).

The above comments and views of these eminent people confirm the fact that Nigeria's educational system has suffered due to unprecedented and ill-timed changes in the educational policies.

The Universal Basic Education is one casualty that is very fresh. The programme was launched in 1999 during the administration of the Nigerian President Olusegun Obasanjo, but the human resources and materials which were needed to implement the programme were not put in place; there were no infrastructure in place and teachers to implement the programme, were taken through a mere five-day training in 2005, six years after launching a programme of such importance. Not long ago, Nigerians woke up to the declaration of Nigeria's former Minister of Education Professor Ruqayyatu Ahmed Rufa'I that president Goodluck Jonathan has approved "reverting the 6-3-3-4 to original intentions and adjusting its structure to include one year Early Childhood Education (ECE) for five-year-olds (1-6-3-3-4)". One cannot but ask what the original intentions were and why those intentions were "safely" kept away all these years only to go back to them now. This change is coming after Nigeria had jettisoned the 6-3-3-4 system for the 9-3-4 and now back to 1-6-3-3-4 to accommodate the "original intentions"? There is no doubting the fact that there have been lots of inconsistencies in the way education policies evolve and dissolve in Nigeria.

\section{The 6-3-3-4 System of Education: An Example of a Failed Policy/System}

This system replaced the previous "bookish" 6-5-2-3 system that "prepared students for basic white collar jobs" (Moja, 2000, p. 19). One of the objectives of splitting secondary education to junior and senior secondary education was to create an exit point after completing junior secondary education, but the implementation of this objective was problematic right from the start (see Table 1). A negligible number of secondary schools received supplies of vocational education equipment, some of which were already obsolete before distribution, while the rest never received theirs till the system was rested. Those that received could not implement because workshops were not built, another was the dearth of qualified vocational teachers to train the students. As a matter of fact, it was an era of mass promotion of students from junior secondary to senior secondary level because there were no workshops to send them for vocational education.

In Kaduna State, then it was reported that:

All the 55,430 pioneer graduates from junior secondary schools have received admission into the 170 senior secondary schools in the state. The state government said that it would not tolerate a situation where 15 -year-olds would be roaming the streets. (New Nigerian, June 5, 1985, cited in Adamu, 1994)

One of the matters arising from this was the unprecedented number of candidates, largely unqualified, 
admitted into higher institutions that were grossly inadequate to accommodate such population; the resultant effect of all these was the churning out of what Professor Pat Utomi described as "certificated illiterates" which is still very prevalent. In the view of Suleiman (2010), the 6-3-3-4 system suffered a serious setback due to improper planning, the system was started in haste, needed manpower was not available, infrastructural facilities were grossly inadequate, etc., which led to serious crises in the education sector. To Olawale (2010), crisis in education started manifesting itself when government went all out to implement the 6-3-3-4 system without adequate planning and roadmap in place. If the system had enjoyed effective implementation, the current agitation for entrepreneurial curriculum would not have arisen, because the vocational and technical aspects of the 6-3-3-4 system would have sufficiently addressed that.

Table 1

Educational Systems From Independence to Date

\begin{tabular}{|l|l|l|l|l|l|l|l|}
\hline Year & $\begin{array}{l}\text { System of } \\
\text { education }\end{array}$ & $\begin{array}{l}\text { Early } \\
\text { childhood/Pre-primary } \\
\text { education }\end{array}$ & $\begin{array}{l}\text { Primary } \\
\text { education }\end{array}$ & $\begin{array}{l}\text { Junior } \\
\text { secondary } \\
\text { education }\end{array}$ & $\begin{array}{l}\text { Senior } \\
\text { secondary } \\
\text { education }\end{array}$ & $\begin{array}{l}\text { Higher school } \\
\text { certificate }\end{array}$ & $\begin{array}{l}\text { Tertiary } \\
\text { education }\end{array}$ \\
\hline$* *$ & $6-5-2-3$ & Nil & 6 years & \multicolumn{2}{|c|}{5 years } & 2 years & 3 years \\
\hline 1982 & $6-3-3-4$ & Nil & 6 years & 3 years & 3 years & Nil & 4 years \\
\hline 1999 & $9-3-4$ & Nil & \multicolumn{2}{|c|}{ 9 years } & 3 years & Nil & 4 years \\
\hline 2012 & $1-6-3-3-4$ & 1 year & 6 years & 3 years & 3 years & Nil & 4 years \\
\hline
\end{tabular}

Note. ${ }^{* *}$ The system started in the pre-colonial time till sometimes in 1982. No document to substantiate the exact year as at the time of writing this paper.

\section{Inconsistent Educational Policy/System: Implication for Curriculum Implementation}

Curriculum implementation is the process of translating theory into practice. Of all the stages in the curriculum process, this is the most crucial stage and "Any policy without effective implementation is no policy" (Suleiman, 2010, p. 282). Any educational policy/system is lifeless until implemented via the curriculum and this act of putting plan into action is always carried out during the instructional process by teachers.

The curriculum is the educational tool used by teachers for the achievement of educational system/policy objectives and whichever way the contents are translated or interpreted is dependent on the information at their disposal and their level of preparedness for the task. As Adamu (1994) noted, the issue facing any change strategy is not just of need, clarity, complexity, or quality of the materials used, but the constant production of personnel who identify with the rationales of the change strategy enough to see to its sustenance to achieve a reasonable measure of its objectives. To Adeyemi (1995, p. 39), "Consent of teachers to an innovation does not necessarily connote that they understand the change... It is realized that teachers who are supposed to implement a new curriculum sometimes cannot even identify its main features". A situation whereby operators of a system do not understand the workings of that system, are ill-prepared and ill-equipped to operate such system as currently done in Nigeria education system will continue to produce same unrealized objectives. This is one blunder too many always packaged with educational policies in Nigeria.

Teachers as can be seen in Figure 1 bring meanings into these policies during the instructional or process else, they remain mere statements on the pages of paper. As Gusau (2008) rightly observed, policy intent is different from policy implementation. Achievement of educational policies/system objectives is directly proportional to the achievement of curriculum objectives during the teaching-learning process. 


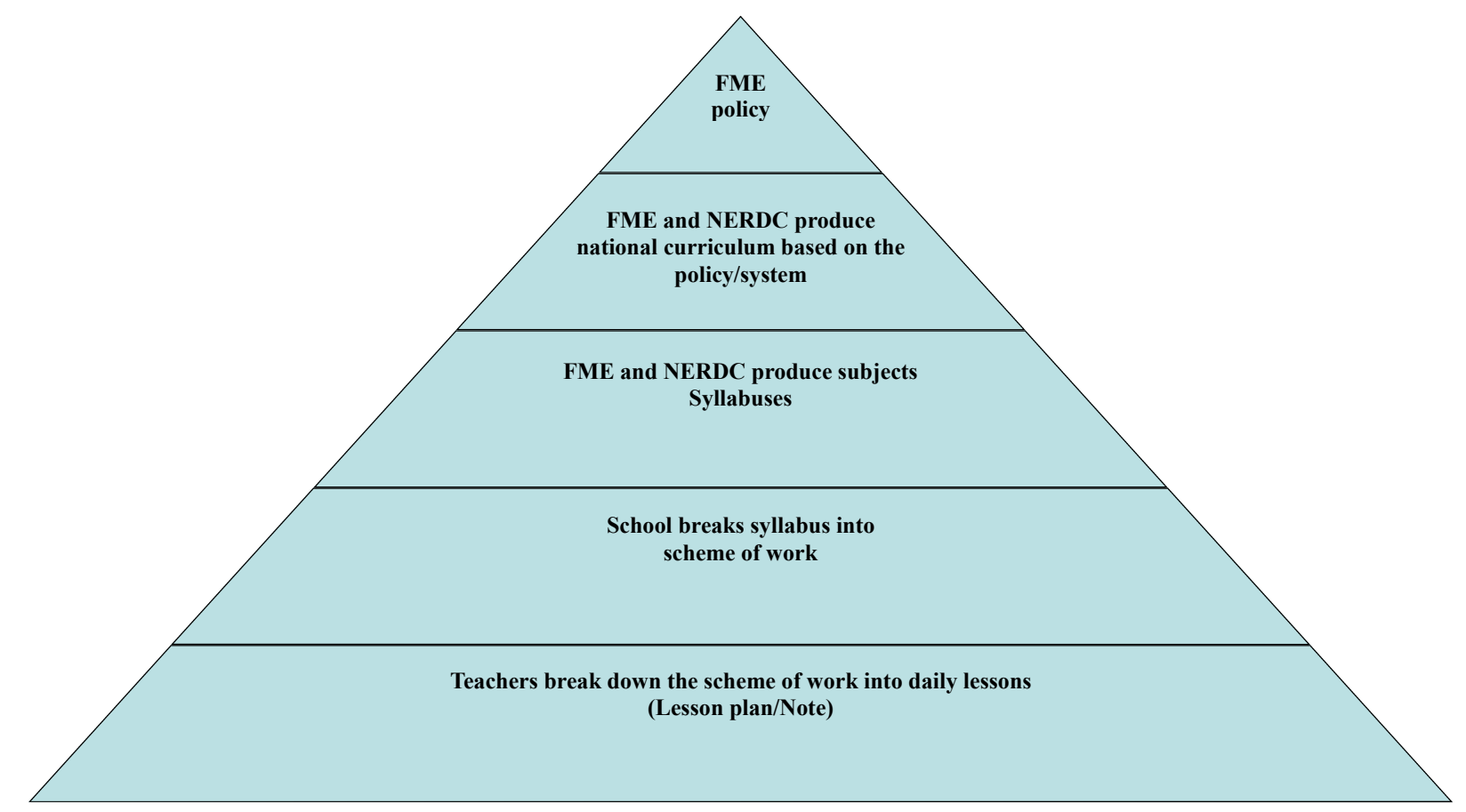

Figure 1. The curriculum as a teaching plan derived from the educational policy/system. Note. FME-Federal Ministry of Education.

The federal government though at the apex of the above pyramid needs the teachers at the base (foundation), failure at the base is failure at the apex and success at the base is success at the apex. Nigerian teachers quite often are not adequately represented or sometimes completely left out in decision-making as it affects education when the onus task of implementing such decisions rests with them. "Most often than not, these teachers are not part of the planning and development of these policies; they only implement anything given them their incompetence at doing so not withstanding" (Asaaju, 2011, p. 165). According to Afe (2003) in Ugodulunwa and Mustapha (2006), even with the best of education policy and design and the expenditure of colossal sum of money for education, the ultimate realization of any set of aims for education depends on the teacher. The achievement of stated objectives at any level of education, primary, secondary, or tertiary is directly proportional to a workable curriculum which in turn is a reflection of the availability, adequacy, and quality of all operational factors.

When these operational factors are either defective, ineffective, or absent, a well-designed and well-planned policy becomes a failure even before its implementation and any attempt to patch up is like trying to build something on nothing. As Asaaju (2010, p. 30) rightly noted, "It is not out of place to assert that the successful implementation of educational goals rests with the teachers but they can only perform effectively this function when adequately equipped to do so", but it is disquieting to note that when it comes to implementing the variables or factors that yield quality education, Nigeria tends to drag its feet (Duze, 2011).

\section{Education Policies in Nigeria: What Is Wrong}

There is nothing wrong with the policy/system, but the mechanism running the policy/system itself is 
ineffective (Olawale, 2010). The public perception is that the quality offered is low and that standards have dropped. These perceptions are based on lack of adherence to acceptable educational practice:

(1) Teacher qualifications are low;

(2) The learning environment does not promote effective learning;

(3) Basic facilities, teaching, and learning resources are not available;

(4) Teacher-student ratios are high;

(5) General performance in examinations is poor;

(6) The graduates have low levels of competencies at work (Moja, 2000, p. 12).

The non-adherence to this acceptable educational practice is the real problem and not the policy/system. Below are some of the comments (retrieved online) of Nigerians on this latest 1-6-3-3-4 system:

The problem with Nigeria is not making policy but rather implementing them. Nigeria has one of the best policies in the world. But can we implement these policies? (Rose Jr. Online, October 10, 2010) ${ }^{1}$

Our policy makers need to identify the true problem of our educational system. This new adoption is nothing but another unnecessary system... (Teejay, Friday, March 16, 2012)

Our leaders do not know the problem of the system. If they like let them change the system to 3-6-3-3-4. The problem is not the system... Repackaging an expired drug does not make the drug good. (Stroud, Wednesday, January 30 , 2012)

My question is will all these reforms correct the decadence in the educational system of Nigeria? What the government is introducing is not different from what has been in the system. (Olufunke Jobberman, Friday, December 9 , 2011)

\section{Some Identified Defective Operational Factors}

\section{Poor Analysis of Problems Confronting the Existing Policy}

Educational system in Nigeria has been that of implementation before policy coherence. Implementation of a new programme/system/policy in Nigeria precedes analysis of the existing situation and planning. Obinna (2007, p. 8) in Onyeachu (2009) noted, "No government policy on education can be realized if it does not first of all perceive the problems and opportunities before initiating decision-making process". As Adamu (1994) posited, changes in education often come about when the current practices are challenged and questions are being asked about the way things are done but the reverse has always been the case in Nigeria. Asaaju (2011, p. 164) believes that "Educational policies are usually not conceived in a rush; it is oftentimes a long term process which involves planning, talks, debates, deliberations, sensitization, and many more before the actual policy is arrived at". Nigeria is always in haste to make changes without adequate diagnosis of issues and challenges militating against the previous plan or programme. An ailment not properly diagnosed attracts the wrong medication and it soon becomes an incurable disease.

\section{Political Instability}

Asaaju (2011, p. 165) believes that "Political instability has led to incessant changes in educational policies... ", but to Ekundayo (2010), educational policies have been observed to change with changes in the political leadership of Nigeria. In the view of Moja (2000, p. 1), "Over the past decade, Nigeria has been plagued by frequent political unrest. This political instability has generated negative effects on the educational system". These statements, however, are incontrovertible but what remains unknown or uncertain is when the

\footnotetext{
${ }^{1}$ Retrieved from http://www.nigeria.myinternetforum.com/index.php?topic=1819.0.
} 
vicious cycle will break in Nigeria; the only thing that is constant is change itself but should every change mean a fresh start? The answer is no.

\section{Accountability}

Though available resources to education are grossly insufficient, there is gross mismanagement of these insufficient resources.

I have also observed in the course of my work as the chairman of a panel of investigation on standard of education in the country that many political office holders lack conscience and spirit of sense of accountability before God and man. (Dr. Sheikh Ahmed Lemu, President, Islamic Education Trust, National Mirror Online, February 9, 2012)

\section{Information/Sensitization}

Nigerians and especially teachers are always not in the know of the different shifts or changes in the educational system. Sometimes as a teacher educator, exuding confidence at discussing the exact educational system Nigeria currently operates is in doubt. In the view of Aghenta (1984), any plan not sold to the consumer remains on paper, like the current 6-3-3-4 structure, many people in Nigeria do not understand what it is and its implication. Below is a personal experience of this writer with a Nigeria public secondary school teacher on May 6, 2012:

The teacher: Good afternoon, please I need instructional materials/textbook(s) on a newly introduced subject into the school curriculum in my discipline.

This author: Which subject is that?

The teacher: Office Practice.

This author: Office Practice or Office Management? Is it a topic?

The teacher: Office Practice. No, it is a subject.

The author could not help her though the teacher believed she should, after all she is a teacher-educator; the truth is, this author was hearing about it for the very first time. Now, this teacher must teach that subject whether she liked it or not. The answer to this puzzle lies in the imagination.

\section{Periodic Monitoring and Evaluation}

Education policies, projects, or programmes most times are devoid of effective monitoring to ensure compliance and implementation according to laid down criteria or intentions. As Moja (2000, p. 18) rightly observed, "inadequate planning and funding as well as the inadequacies of the monitoring processes for the implementation of national policy on education contributed to a lack of classroom space in the sub-sector".

\section{Relevance of Change to Society's Philosophy and Needs}

No policy on education, however, can be formulated without first identifying the overall philosophy and goals of the nation... The country's educational goals shall be clearly set out in terms of their relevance to the needs of the individual and those of the society, in consonance with the realities of our environment and the modern world. (Federal Republic of Nigeria, 2004, p. 6)

Though Osokoya (2003) observed that the early educational policies failed to provide Nigerians with adequate philosophy, national goals, and objectives of education, the recent policies have not in any way fared better. One of the highlights of the 1925 memorandum of the Phelps Stokes Commission was,

That education should be adapted to the local conditions in such a manner as would enable it to conserve all sound elements in local tradition and social organization, while at the same time functioning as an instrument of progress and 
evolution. (Fafunwa, 1974, p. 124)

Policies must be formulated in consonance with relevance to the needs, goals, and aspirations of the society in which they are to be implemented. Reiterating this view, Fafunwa posited that "Any self-respecting nation must fashion its educational system according to its own thinking, needs, temperament, and limitations" (Fafunwa, 1970, p. 3), but what is in operation negates these policy statements and position. The Academic Staff Union of Universities (ASUU), through its president Professor Awuzie declared, “... the federal and state governments in Nigeria have been both unable and unwilling indeed, they have refused to embark on policies which focus on a sustained path of people-oriented and anti-imperialist national development".

Till date, Nigeria school curriculum still has its roots firmly entrenched in the British curriculum 51 years after independence. Though there may not be a complete detachment from this source, why not adaptation? A complete adoption of foreign values and philosophy has produced Nigerians without clear-cut identities; they are neither educated Nigerians nor educated Britons.

\section{Funding}

It is no longer a matter for debate though a debacle that the education sector suffers from gross underfunding when compared with other sectors of the Nigerian economy in spite of government's affirmation that "Education is an instrument for national development" (Federal Republic of Nigeria, 2004, p. 6). To Duze (2011), Nigeria has not invested heavily in education in recent years, despite massive expansion in this sector. The UNESCO (United Nations Educational, Scientific, and Cultural Organization) recommendation of at least $26 \%$ of budgetary allocation to education by member nations has not seen the light of day in Nigeria. Records have shown that the highest committal to education between 1999 and 2010 was 13\% (see Table 2). Inadequate funding is evident in the infrastructural decay plaguing public schools and institutions in Nigeria. How effective are policies in the absence of adequate funding? Citing Ivowi (2004) in Onyeachu (2009), to ensure that curriculum is effectively implemented, infrastructural facilities, equipment, tools, and materials must be provided in adequate quantities.

Table 2

Federal Government's Allocation to Education (1999-2010) and UNESCO's Recommendation Compared

\begin{tabular}{lllllll}
\hline Year & $\begin{array}{l}\text { Allocation }(\mathrm{N} \\
\text { billion) }\end{array}$ & $\begin{array}{l}\text { UNESCO } \\
\text { recommendation } \\
\text { in N billion }\end{array}$ & $\begin{array}{l}\text { Percentage of } \\
\text { Nigeria's budget } \\
(\%)\end{array}$ & $\begin{array}{l}\text { UNESCO (\%) } \\
\text { Shortfall in N }\end{array}$ & $\begin{array}{l}\text { UNESCO (\%) } \\
\text { shortfall }\end{array}$ \\
\hline 1999 & 23.0 & 53.3 & 11.2 & 26 & 30.3 & 14.8 \\
2000 & 44.2 & 138.6 & 8.3 & 26 & 94.4 & 17.7 \\
2001 & 39.9 & 148.2 & 7.0 & 26 & 108.3 & 19.0 \\
2002 & 100.2 & 510.8 & 5.1 & 26 & 410.6 & 20.9 \\
2003 & 64.8 & 142.8 & 11.8 & 26 & 78.0 & 14.2 \\
2004 & 72.2 & 240.7 & 7.8 & 26 & 168.5 & 18.2 \\
2005 & 92.6 & 290.1 & 8.3 & 26 & 197.5 & 17.7 \\
2006 & 166.6 & 497.9 & 8.7 & 26 & 331.3 & 17.3 \\
2007 & 137.5 & 586.1 & 6.1 & 26 & 448.6 & 19.9 \\
2008 & 210.0 & 420.0 & 13.0 & 26 & 210.0 & 13.0 \\
2009 & 183.4 & 662.3 & 7.2 & 26 & 478.9 & 18.8 \\
2010 & 249.1 & $1,012.0$ & 6.4 & 26 & 762.9 & 19.6 \\
\hline
\end{tabular}


The table above is a clear indication of gross underfunding of education in Nigeria. The recommended $26 \%$ of budgetary allocation if implemented will still not be sufficient to effectively fund education in Nigeria, but when the total percentage budgeted is even less than half of the recommended percentage, the outcome is left to the imagination.

\section{Legislative Backing for Educational Policies}

According to Ajayi (1983), the existence of a legal organizational structure requires a legal control system of education at various levels to ensure that the education industry provides sanctions and guidelines defining the powers, functions, rights, and obligations of all the participants geared toward the efficiency of the teaching learning process. The Executive Secretary of the NERDC, Professor Godswill Obioma advised in an interview granted the Daily Champion and published online on February 13, 2010, in ensuring implementation of the roadmap for the education sector, Nigeria must be ready to adopt the Indonesian approach by defending education policies on the floor of the National Assembly. The education sector derives its legal backing from the 1979 Constitution but enforcement and no enactment has always been the problem of Nigerian Acts and Laws.

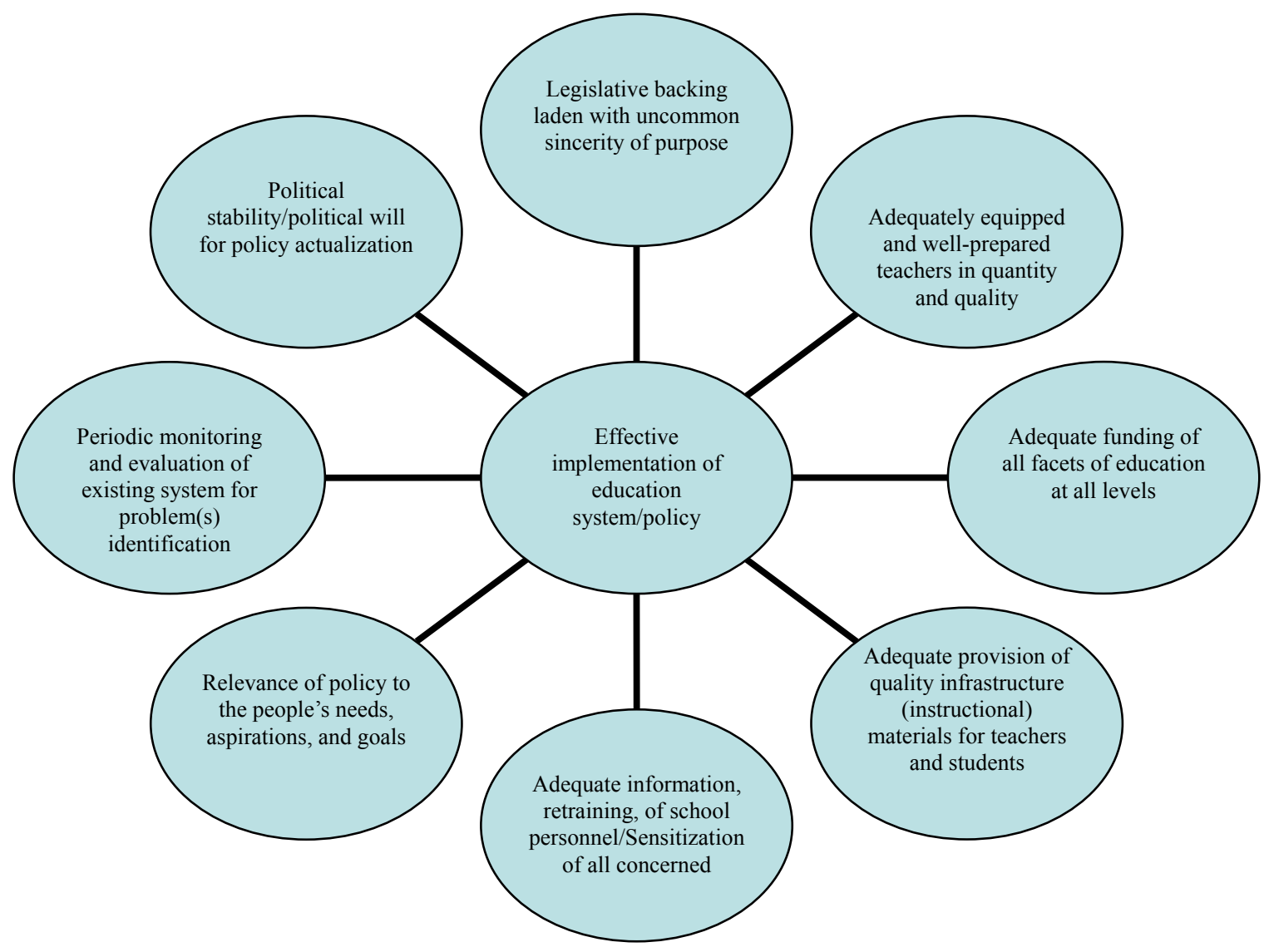

Figure 2. Operational factors for effective implementation of educational system/policy.

\section{Conclusions}

The rate at which educational policies especially are altered or discarded has become not only 
embarrassing but worrisome; this portrays Nigeria as a nation of unserious and confused people who either do not know what they need or not know how to go about getting what they need. Successive governments and administrations in Nigeria have handled education issues in a manner that depicts poor understanding of its significance to a nation's growth and development. The time for a complete overhaul of the entire education structure in Nigeria is now as any further delay could be fatal not only to the education system but the nation as a whole. This overhaul must be laden with uncommon sincerity of purpose and collective political will to put an end to this man-made comatose that has bedeviled the sector over the years.

Education remains the most potent tool and an indispensable one at that to get Nigeria out of the economic quagmire it is presently enmeshed in. A vast majority of Nigerians are not proud to send their children to Nigeria public schools, a situation that has given private school owners the impetus to exploit Nigerians without batting an eyelid. Even the Nigerian president's children are enrolled in foreign schools right inside Nigeria. The Federal Government of Nigeria cannot continue to display a sense of satisfaction with the present state of its education in which Nigerians who get exposed to it cannot plough back knowledge acquired into the society.

Education shall continue to be highly rated in the national development plans because education is the most important instrument of change; any fundamental change in the intellectual and social outlook of any society has to be preceded by an educational revolution. (Federal Republic of Nigeria, 2004, p. 8)

The above policy statement from the Federal Government of Nigeria sums up the important and crucial role education is expected to or can play in overall national development but achievement will depend to a very great extent on government's readiness to do what is right as identified in Figure 2. These are just some of the operational factors that must accompany any educational policy for successful implementation and achievement of objectives.

\section{Recommendation}

(1) Availability of adequate information to and sensitization of all stakeholders in the change process: All stakeholders must be adequately informed and prepared for the impending change to forestall subtle resistance or rejection. Here, teachers are the primary focus. The policy statement, "No education system may rise above the quality of its teachers" (Federal Republic of Nigeria, 2004, p. 39), sums up the fact that the dependency of a workable education system rests on the quality of teachers at whatever level of education;

(2) Provision of adequate, quality, and functional infrastructure that are commensurate with the population and needs of teachers and learners;

(3) There is no doubting the fact that "Education is an expensive social service... requires adequate financial provision from all tiers of government for successful implementation of the educational programmes" (Federal Republic of Nigeria, 2004, p. 61, Section 13, Article 120). Government's sincerity to this statement should begin with the implementation of the recommended $26 \%$ of budgetary allocation by UNESCO to fund education without further delay;

(4) Training and re-training of teaching and non-teaching personnel at the expense of government who are the sole proprietors of these schools and employers of these personnel. If non-governmental agencies or the private sector must assist in funding any aspect of education, government at whatever level must be seen to be playing its own part and sincerely too; 
(5) Legislation on all educational policies should be enforced and sanctions imposed for poor or non-implementation where necessary to serve as deterrent to others especially at state and local levels. The Federal Government of Nigeria may not be morally justified to wield the big stick because it is also non-compliant with policy implementation issues in education;

(6) Periodic monitoring and evaluation of systemic issues and state of physical facilities, the feedback from which prompt action must be taken to remedy any untoward situation for sustenance of standards. The inspectorate arm of the ministries of education (federal and states) must be trained on quality assurance as it affects each aspect of education. A one-for-all inspector policy should be discarded. Areas such as the curriculum implementation, physical facilities, staff training, staff strength, student population, instructional materials (availability and adequacy), instructional process, etc., must be periodically monitored and evaluated. Sometimes, one is constrained to believe that these inspectors do not know what exactly to look out for or, their reports end up as trash;

(7) The education system should be re-defined to reflect the true philosophy of the Nigerian nation "in consonance with the realities of our environment" (Federal Republic of Nigeria, 2004, p. 6) and implemented to the letter.

\section{References}

Adamu, A. U. (1994). Educational reforms in Nigeria. Retrieved from http://www.kanoononline.com/publications/educational_ reform_in_nigeria.htm

Adeyemi, M. A. (1995). Curriculum change and innovation: Impact on science curriculum projects. Lagos: Deutchetz Publishers.

Aghenta, J. A. (1984). Towards a systems approach to the planning of secondary education in Nigeria. In S. Adesina (Ed.), Secondary education in Nigeria (pp. 227-243). Ile-Ife: University of Ife Press.

Ajayi, K. (1983). An appraisal of the legal structure of education in Nigeria. Retrieved from www.unilorin.edu.ng/journals/ education/ije/feb1983/

Akindele, F., \& Adegbite, W. (2005). The sociology and politics of English in Nigeria: An introduction. Ile-Ife: O.A.U. Press.

Asaaju, O. A. (2010). Improving the quality of teacher education for sustainable development. African Journal of Historical Sciences, 6(2), 23-36.

Asaaju, O. A. (2011). Appraising the quality of teachers in the provision of functional education needed for manpower development. African Journal of Social Research and Development, 3(2), 162-168.

Awuzie. (2010). ASUU blames government for poor performance in education. Retrieved from http://www.nigerianbestforum. com/generaltopics/ $\mathrm{p}=44553$

Comments on the failure of education policies in Nigeria. (2012). Retrieved from http://www.thetimesofnigeria.com/ Article.aspx?id=3465

Duze, C. O. (2011). Falling standard in Nigeria education: Traceable to proper skills-acquisition in schools? Educational Research Journal, 2(1), 803-808. Retrieved from http://www.interesjournals.org/ER

Ekundayo, H. T. (2010). Administering secondary schools in Nigeria for quality output in the 21 st century: The principals' challenge. European Journal of Educational Studies, 2(3), 187-192.

Fafunwa, A. B. (1970). A history of higher education in Nigeria (1827-1969). Lagos: Macmillan.

Fafunwa, A. B. (1974). History of education in Nigeria. London: George Allen \& Unwin.

Federal Ministry of Education (Nigeria). (n.d.). Wikipedia, the free encyclopedia. Retrieved from http://en.wikipedia.org/ wiki/Nigerian_Federal_Ministry_of_Education

Federal Republic of Nigeria. (2004). National policy on education (4th ed.). Lagos: NERDC Press.

Gusau, B. U. (2008). Educational reforms in Nigeria: Successive years of inconsistencies and confusions. Retrieved from http://www.gamji.com/article6000/NEWS7831.htm

Moja, T. (2000). Nigeria education sector analysis: An analytical synthesis of performance and main issues. New York: World Bank Document. 
Olawale, O. (2010, April 8). Challenges currently facing the education sector in Nigeria. The Fronteira Post. Retrieved from http://www.valuefronteira.com/index /post-format

Onyeachu, J. A. E. (2009). Implementation issues in secondary education curriculum in Nigeria: Problems and prospects. International Journal of Research Development, 1(4), 565-574.

Osokoya, I. O. (2003). 6-3-3-4 education in Nigeria: Strategies, issues and problems. Ibadan: Laurel Educational Publishers Ltd.

Suleiman, H. (2010). Effective policy implementation: A prerequisite for sustainable development. African Journal of Historical Sciences, 6(2), 280-286.

Ugodulunwa, C. A., \& Mustapha, A. Y. (2006). Construct validation of a teacher effectiveness scale. Nigerian Journal of Professional Teachers, 1(4), 60-71. 